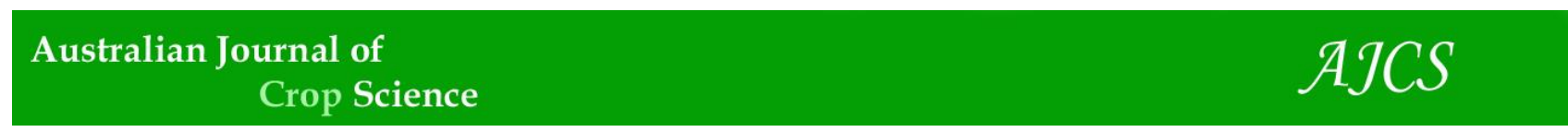

AJCS 10(11):1557-1563 (2016)

ISSN:1835-2707

doi: 10.21475/ajcs.2016.10.11.PNE156

\title{
Influence of gypsum application on sugarcane yield and soil chemical properties in the brazilian Cerrado
}

\section{Larissa Gomes Araújo ${ }^{1}$, Cícero Célio de Figueiredo ${ }^{1 *}$, Djalma Martinhão Gomes de Sousa ${ }^{2}$, Rafael de Souza Nunes', Thomaz Adolpho Rein ${ }^{2}$}

${ }^{1}$ Faculty of Agronomy and Veterinary Medicine, University of Brasília, 70910970 Brasília, DF, Brazil

${ }^{2}$ Brazilian Agricultural Research Corporation (EMBRAPA), Embrapa Cerrados, Planaltina, DF, Brazil

\section{*Corresponding author: cicerocf@unb.br}

\begin{abstract}
Cerrado soils generally have low levels of exchangeable bases and high aluminum toxicity. These conditions can limit crop development. In view of the expansion of sugarcane cultivation in the Cerrado region, technologies that allow higher yields are required. Therefore, the objective of this study was to evaluate the influence of gypsum on sugarcane yield and soil chemical properties. The experiment was carried out in a randomized block design with four replications and two treatments: control without gypsum $\left(0 \mathrm{Mg} \mathrm{ha}^{-1}\right)$ and application of the recommended dose $\left(5 \mathrm{Mg} \mathrm{ha}^{-1}\right)$ for sugarcane. Cane and sugar yield were evaluated in four cuts. Seven soil layers $(0-5 ; 5-10 ; 10-20 ; 20-40 ; 40-60 ; 60-80$, and $80-100 \mathrm{~cm})$ were sampled after harvesting the third ratoon crop, 50 months after gypsum application, to determine $\mathrm{pH}$ in $\mathrm{H}_{2} \mathrm{O}$ and $\mathrm{CaCl}_{2}$; aluminum $\left(\mathrm{Al}^{3+}\right)$ exchangeable cations $\left(\mathrm{Ca}^{2+}, \mathrm{Mg}^{2+}\right.$ and $\left.\mathrm{K}^{+}\right)$, potential acidity $(\mathrm{H}+\mathrm{Al})$; sulfur $\left(\mathrm{S}_{-}-\mathrm{SO}_{4}{ }^{2-}\right)$. Gypsum application increased cane and sugar yield in all four cuts, and resulted in higher $\mathrm{Ca}^{2+}, \mathrm{Mg}^{2+}$ and $\mathrm{SO}_{4}{ }^{2-}$ levels and lower aluminum saturation in the 20-100, 40-100, 0-100, and 40-100 cm layers, respectively. In addition, the application of gypsum provided an increase in cation exchange capacity in the 40-100 cm layer. Therefore, gypsum application is recommended to improve the chemical conditions of the soil and to increase sugarcane productivity in the Cerrado.
\end{abstract}

Keywords: aluminum saturation; Saccharum spp.; sugarcane productivity; subsoil acidity; sugar yield.

Abbreviations: m_aluminum saturation; V_base saturation; OM_organic matter.

\section{Introduction}

In the 2015/16 growing season, Brazil is expected to produce sugarcane on about nine million hectares (CONAB, 2015). The national mean yield expected for this harvest is around $73.2 \mathrm{Mg} \mathrm{ha}^{-1}$, although the yield potential can exceed $200 \mathrm{Mg}$ ha $^{-1}$ (Waclawovsky et al., 2010). In addition to the plant physiological traits, the crop contributes to a reduction in greenhouse gas emissions, since one of the products resulting from processing is ethanol, which is an important component of the Brazilian energy matrix (Macedo et al., 2008).

One of the main limiting factors of sugarcane productivity is water stress (Basnayake et al., 2012). The impacts caused by rainless periods in the Cerrado may be intensified by aluminum toxicity and calcium deficiency in the subsurface soil layers (Ritchey et al., 1982). Under these conditions, root growth is restricted and thus limiting the access to water and nutrients available in the soil profile (Sousa and Lobato, 2004; Caires et al., 2006; Almeida et al., 2015). Agricultural or mineral gypsum $\left(\mathrm{CaSO}_{4} \cdot 2 \mathrm{H}_{2} \mathrm{O}\right)$ is being widely used as source of nutrients such as calcium and sulfur and to adjust aluminum toxicity in the deeper soil layers (Caires et al., 2006; Nora and Amado, 2013), after correction of the $\mathrm{pH}$ in the surface layer by liming. Some studies have indicated that gypsum is an important complement to liming in the presence of high $\mathrm{Al}^{3+}$ levels in the subsoil (Soratto and Crusciol, 2008; Caires et al., 2010; Crusciol et al., 2016). Thus, gypsum is considered a subsurface amendment for root growth, reducing toxic levels of aluminum and increasing calcium levels in the soil profile (Caires et al., 2002; Pauletti et al., 2014). Gypsum can promote changes to chemical properties of deeper soil layers and this ability is due to its higher solubility compared to lime and the effect of the accompanying anion. During the reaction of soil acidity correction by the use of lime the carbonate is consumed and becomes unavailable to accompany calcium to the deeper soil layers, while for gypsum the sulfate remains available (Ritchey et al., 1980). These benefits can reduce the adverse effects of drought periods, and consequently yield losses, consolidating the stability of agricultural production of Brazil, especially in the Cerrado region. Sugarcane requires high water availability $(1100-1300 \mathrm{~mm}$ in the Central-West region) with regular distribution throughout the cycle (Hernandes et al., 2014). Nevertheless, the subsurface chemical traits of the Oxisols can influence sugarcane productivity due to variation in the sum of bases and contents of calcium and organic matter (Landell et al., 2003). These characteristics, particularly in view of the expansion of the crop into the Cerrado (Adami et al., 2012), calls for technologies that minimize the risk of yield losses.

Since gypsum application may be a viable solution for the reduction of these potential losses, this technology should be investigated in more detail in the Cerrado. Thus, the purpose of this study was to evaluate the influence of gypsum application on the cane and sugar yield and also on the chemical properties of an Oxisol in the Cerrado. 


\section{Results and discussion}

\section{Sugarcane and sugar yield}

Gypsum application increased cane and sugar yield. This higher yield occurred along the four sugarcane crop cycles, in which cane yield ranged between 69 and $143 \mathrm{t} \mathrm{ha}^{-1}$ (Fig 1a) and sugar yield ranged between 13 and $25 \mathrm{tha}^{-1}$ (Fig $1 \mathrm{~b}$ ). The treatment of plant cane under gypsum application produced a 74,42 and $23 \%$ higher cane yield than the first, second and third ratoon crop, respectively. The higher cane plant yield was associated with stronger growth and greater branching of the root system, compared with the ratoon crop (Smith et al., 2005; Battie-Laclau and Laclau, 2009). The increases in cane yield under gypsum applications increased from the sugarcane plant to the three evaluated ratoons in relation to non-gypsum application, with observed values of 10, 19, 20, and $21 \%$ for cane plant, and the first, second and third ratoon, respectively.

The increasing productivity gains observed from the sugarcane plant after gypsum application were associated with sulfur $\left(\mathrm{S}_{-} \mathrm{SO}_{4}^{-2}\right)$ supply, which is among the five most required nutrients of sugarcane. In the mean, $0.37 \mathrm{~kg}$ of $\mathrm{S}$ is exported by the production of one ton of cane (Thangavelu and Rao, 2006) and continuous sugarcane cultivation results in a greater export of this nutrient, increasing the magnitude in the response of ratoon crops, compared to non-application of $\mathrm{S}$ in the treatment without gypsum. Another factor favoring the trend of increasing increments in sugarcane productivity is the increase in calcium levels in the deeper soil layers due to the movement of $\mathrm{S}_{-} \mathrm{SO}_{4}^{-2}$ (Lima et al., 2013).

\section{Soil pH}

Gypsum application raised the $\mathrm{pH}$ values in $\mathrm{H}_{2} \mathrm{O}$ in the 60$100 \mathrm{~cm}$ layer and $\mathrm{pH}$ in $\mathrm{CaCl}_{2}$ in the $40-100 \mathrm{~cm}$ layer, 50 months after application (Fig 2a, 2b). However, for the 0-40 $\mathrm{cm}$ layer this effect was not observed, probably due to incorporation of $7 \mathrm{t} \mathrm{ha}^{-1}$ lime in the two treatments, the recommended dose to raise soil base saturation to $50 \%$ in that layer. The $\mathrm{pH}$ values in $\mathrm{H}_{2} \mathrm{O}$ ranged from 4.5 to 5.9 , while lower values were observed for $\mathrm{pH}$ in $\mathrm{CaCl}_{2}(4.1$ - 5.0) in all layers, regardless of gypsum application, confirming the predominance of negative charges in the soil profile. Unlike for $\mathrm{pH}$ in $\mathrm{CaCl}_{2}$, the presence of soluble salts can interfere with the determination of $\mathrm{pH}$ in $\mathrm{H}_{2} \mathrm{O}$, due to the electrolytes contained in the solution (Schofield and Taylor, 1955). This condition may have been one of the reasons that the increase in $\mathrm{pH}$ in response to gypsum application in the $40-60 \mathrm{~cm}$ layer was only detected in $\mathrm{CaCl}_{2}$.

The $\mathrm{pH}$ increase in the deeper layers resulting from gypsum application is associated to the displacement of hydroxyl (OH-) from the surfaces of iron and aluminum oxides and hydroxides by sulfate ions $\left(\mathrm{SO}_{4}^{-2}\right)$, when dissociated from calcium $\left(\mathrm{Ca}^{2+}\right)$, an effect known as self-liming (Reeve and Summer, 1972; Caires et al., 2006). Although the adsorption sites on the clay surfaces have less preference for $\mathrm{SO}_{4}{ }^{-2}$ than $\mathrm{OH}-$, the displacement is promoted by the effect of the higher $\mathrm{SO}_{4}^{-2}$ concentration in the soil profile after gypsum application.

\section{Aluminum toxicity}

The exchangeable aluminum content $\left(\mathrm{Al}^{3+}\right)$ was reduced by gypsum application in the 20-40 and 60-80 cm layers and unchanged in the other layers (Fig 2c). For aluminum saturation (m), reductions of 12,29 and $28 \%$ were found in the $40-60 ; 60-80$ and $80-100 \mathrm{~cm}$ layers, respectively, in response to gypsum application (Fig 2d). The reduction in exchangeable $\mathrm{Al}^{3+}$ and aluminum saturation $(\mathrm{m})$ is related with hydrolysis and $\mathrm{Al}^{3+}$ precipitation caused by the increase in $\mathrm{pH}$ in response to gypsum application and increases in $\mathrm{Ca}^{2+}$, and $\mathrm{Mg}^{2+}$ contents (Fig 2e, 2f). In addition, ion pair formation of $\mathrm{Al}$ with $\mathrm{SO}_{4}^{+}\left(\mathrm{AlSO}_{4}^{+}\right)$in the soil solution, which is a major mechanism for reducing the activity of aluminum $\left(\mathrm{Al}^{3+}\right.$ species). The formation of $\mathrm{AlSO}_{4}^{+}$ions, which have a lower valence than $\mathrm{Al}^{+3}$, increases the mobility in the soil profile and reduces aluminum saturation (Nora and Amado, 2013).

The toxicity of $\mathrm{Al}^{3+}$ in the subsurface soil layers compromises root growth which reduces nutrient and water uptake, thus affecting productivity (Pavan et al., 1982). In a study with sugarcane clones, Landell et al. (2003) demonstrated an inverse relationship between the exchangeable $\mathrm{Al}^{3+}$ content and mean yield of the third ratoon crop. In this study, gypsum application was effective in reducing aluminum saturation to less than $18 \%$ (Fig 2d).

\section{Exchangeable cations}

The exchangeable calcium content $\left(\mathrm{Ca}^{2+}\right)$ in the soil layers without gypsum application varied from 0.1 to $2.4 \mathrm{cmol}_{\mathrm{c}} \mathrm{dm}^{-}$ ${ }^{3}$, while under gypsum application, the levels varied from 0.8 to $3.0 \mathrm{cmol}_{\mathrm{c}} \mathrm{dm}^{-3}$. Thus, gypsum application increased $\mathrm{Ca}^{2+}$ content throughout the evaluated soil profile, with no significant effect only for the top soil layer $(0-20 \mathrm{~cm})$ (Fig $2 \mathrm{e})$. The $\mathrm{Ca}^{2+}$ deficiency in the subsurface layers of Cerrado soils limits root growth of agricultural crops (Ritchey et al., 1982). The increase in $\mathrm{Ca}^{2+}$ exchangeable content in the soil profile after gypsum application was reported in many studies (Caires et al., 2006; Pauletti et al., 2014), mainly due to $\mathrm{Ca}^{2+}$ supply in the subsurface layers (below $20 \mathrm{~cm}$ ). Gypsum application favored higher contents than $0.8 \mathrm{cmol}_{\mathrm{c}} \mathrm{dm}^{-3}$ throughout the evaluated soil profile (Fig 2e).

In view of the low levels of $\mathrm{Ca}^{2+}$ in Cerrado soils and the recent expansion of sugarcane in this region, raising the levels of this nutrient by gypsum represents an important strategy for the sustainability of this crop under the soil and climatic conditions of the Cerrado. Calcium ions play an important role in root growth and cell wall stability (Marschner, 2012). In addition, studies conducted by Tuteja and Mahajan (2007) demonstrated an important function of this nutrient in the recognition of and adaptation to stress conditions such as extreme temperatures, water stress and salinity.

Gypsum increased the exchangeable magnesium $\left(\mathrm{Mg}^{2+}\right)$ contents in the deepest three studied soil layers (40-60, 60-80 and $80-100 \mathrm{~cm}$ ) (Fig 2f). This was probably related to the reaction of cation exchange favored by gypsum application, after adjusting the acidity of the surface layers with dolomitic limestone. The supply of $\mathrm{Ca}^{2+}$ by gypsum solubilization provides the substitution of $\mathrm{Mg}^{2+}$ from the exchange complex to the soil solution, and consequently the formation of the ion pair $\mathrm{MgSO}_{4}{ }^{0}$, promoting the movement of this nutrient in the soil profile.

Recent research (Cakmak, 2013) pointed out the important function of $\mathrm{Mg}^{2+}$ in the development of wheat roots, where restrictions and decline of the root surface were induced by the deficiency of this nutrient, causing negative impacts on water uptake by the roots, especially under water stress and nutrient deficiency in the soil. 
Table 1. Soil chemical properties of the experimental area prior to liming and fertilization ${ }^{\mathrm{a}}$.

\begin{tabular}{|c|c|c|c|c|c|c|c|c|c|c|c|}
\hline Layer & $\mathrm{pH}$ & $\mathrm{Al}^{3+}$ & $\mathrm{Ca}^{2+}$ & $\mathrm{Mg}^{2+}$ & $\mathrm{K}^{+}$ & CEC & $\mathrm{m}^{\mathrm{b}}$ & $\mathrm{V}^{\mathrm{c}}$ & $\mathrm{OM}^{\mathrm{d}}$ & $\mathrm{S}-\mathrm{SO}_{4}{ }^{2}$ & $\mathrm{P}$ \\
\hline $\mathrm{cm}$ & & & ------ & $\mathrm{cmol}_{\mathrm{c}}$ & ----- & ------ & ----- & -- & $\mathrm{g} \mathrm{kg}^{-1}$ & $---n$ & --- \\
\hline $0-20$ & 4.9 & 1.16 & 0.19 & 0.06 & 0.09 & 8.6 & 77 & 4 & 2.4 & 4.4 & 0.8 \\
\hline $20-40$ & 5.0 & 0.93 & 0.27 & 0.02 & 0.05 & 6.9 & 73 & 5 & 1.8 & 3.4 & 0.6 \\
\hline $40-60$ & 5.0 & 0.61 & 0.16 & 0.01 & 0.03 & 5.5 & 75 & 4 & 1.4 & 2.8 & 0.5 \\
\hline
\end{tabular}

(a)

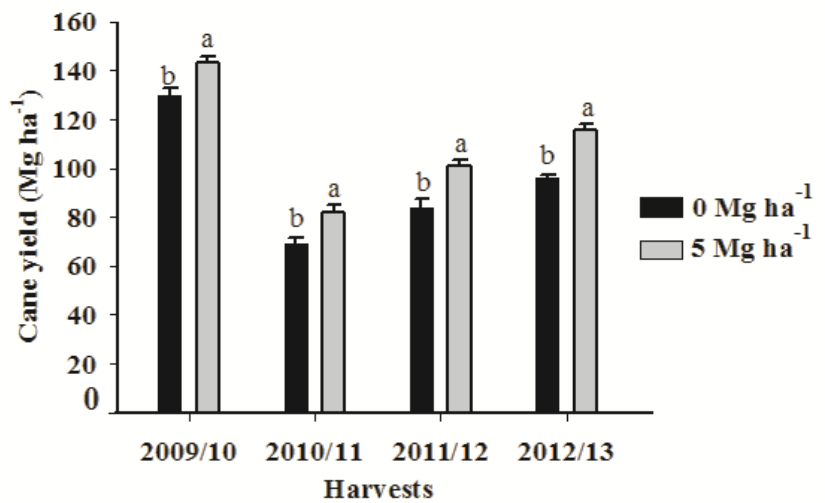

(b)

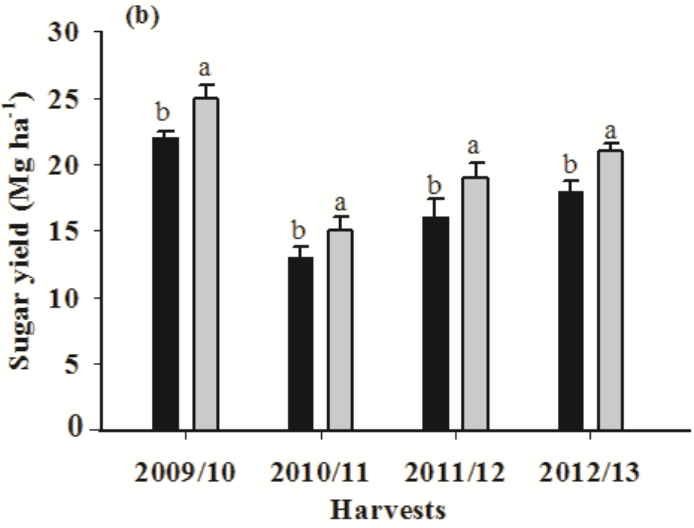

Fig 1. Cane yield $\left(\mathrm{Mg} \mathrm{ha}^{-1}\right)$ (a) and sugar yield $\left(\mathrm{Mg} \mathrm{ha}^{-1}\right)(\mathrm{b})$ in the plant cane cycle (2009-10), and the first ratoon (2010-11), second ratoon (2011-12) and third ratoon crop (2012-13) in response to gypsum rates applied at sugarcane planting. * Significant by the t test $(\mathrm{p} \leq 0.05)$. Bars indicate standard errors $(\mathrm{n}=4)$.

Unlike the behavior observed for $\mathrm{Ca}^{2+}$ and $\mathrm{Mg}^{2+}$, gypsum application does not alter the $\mathrm{K}^{+}$content in the soil (Fig $2 \mathrm{~g}$ ). Thus, no $\mathrm{K}^{+}$leaching caused by gypsum was observed in the 0-100 cm soil layer, even after 50 months of gypsum application, which is probably associated with the application of the appropriate dose recommended for this soil. Similar results were reported by Caires et al. (2006) after 55 months of gypsum application.

\section{Sulfur}

Of the soil nutrients, sulfur was most increased by gypsum application. This treatment increased $\mathrm{S}_{-} \mathrm{SO}_{4}{ }^{2-}$ levels in all soil layers (Fig 2h). The largest increase in $\mathrm{S}^{-\mathrm{SO}_{4}}{ }^{2-}$ was found in the 40-60 cm layer $\left(1 \mathrm{cmol}_{\mathrm{c}} \mathrm{dm}^{-3}\right)$ with contents seven and four times higher than in the $0-20$ and $20-40 \mathrm{~cm}$ layers, respectively, in the gypsum treatment. This shows the movement of S-SO ${ }_{4}^{2-}$ in the soil profile after 50 months, with a total of $5535 \mathrm{~mm}$ precipitation $(514 \mathrm{~mm}$ in the form of supplemental irrigation and $5021 \mathrm{~mm}$ as rainfall). A similar $\mathrm{SO}_{4}{ }^{2-}$ movement was described by Ritchey et al. (1995) after precipitation of $4577 \mathrm{~mm}$.

Changes in $\mathrm{S}_{-} \mathrm{SO}_{4}{ }^{2-}$ were probably favored by $\mathrm{pH}$ correction with limestone and phosphate fertilization in the 0 $40 \mathrm{~cm}$ layer. The reason is that the retention of $\mathrm{S}_{-} \mathrm{SO}_{4}{ }^{2}$ is reduced after correction of soil acidity and repulsion of this anion by phosphate (Caires et al. 2006). On the other hand, in the layers with higher acidity $(40-100 \mathrm{~cm}) \mathrm{S}_{-} \mathrm{SO}_{4}{ }^{2-}$ is retained with greater intensity, which favors the long-term residual effect of this input, when applied to Cerrado soil (Fig 2h). This movement confirms the action of gypsum as conditioner of the root environment, promoting $\mathrm{Ca}^{2+}$ and $\mathrm{Mg}^{2+}$ displacement in the deeper layers and a reduction in $\mathrm{Al}^{3+}$ toxicity (Fig 2e, 2f and 2d).

The increase in $\mathrm{SO}_{4}{ }^{2-}$ content in the $20-100 \mathrm{~cm}$ layer, and with greater intensity between 20 and $80 \mathrm{~cm}$ (Fig 2h), is in line with the assumption of gypsum recommendation for perennial crops, based to adjust the $20-80 \mathrm{~cm}$ layer to a better development of the root system of perennial species (Sousa and Lobato, 2004).

\section{Cation exchange capacity}

Another important consequence of the increase in basic cations such as $\mathrm{Ca}^{2+}$ and $\mathrm{Mg}^{2+}$, resulting from gypsum application, observed in the 40-60, 60-80 and 80-100 cm layers was the rise of the cation exchange capacity at $\mathrm{pH} 7$ (CEC pH 7), with significant increases of 17,25 and $22 \%$, respectively (Fig 3). This represented an increase of 3.28 $\mathrm{cmol}_{\mathrm{c}} \mathrm{dm}^{-3}$ in CEC $\mathrm{pH} 7$ in the 40-100 $\mathrm{cm}$ layer, in the treatment with gypsum compared to that without gypsum. This fact of generation of negative charges in the Cerrado soil, especially in deeper layers, is highly relevant for cation retention, since the mineral fraction of these soils contributes slightly to $\mathrm{CEC} \mathrm{pH}$ 7, for being low-activity clays.

\section{Materials and methods}

\section{Description and management of the experimental area}

The experiment was conducted in an experimental area of Embrapa Cerrados, in Planaltina, Federal District, Brazil (latitude $15^{\circ} 36^{\prime} \mathrm{S}$, longitude $47^{\circ} 42^{\prime} \mathrm{W}$; altitude $1014 \mathrm{~m}$ asl). According to the Köppen classification, the climate is Cwa, with a mean annual rainfall of $1,500 \mathrm{~mm}$ and mean annual temperature of $21.3^{\circ} \mathrm{C}$. The original vegetation was Cerrado sensu stricto and the soil was classified as an Oxisol (Rhodic Haplustox), (Soil Survey Staff, 1998), or Latossolo Vermelho distrófico, according to the Brazilian Soil Classification (Embrapa, 2013), or Rhodic Ferralsol (FAO, IUSS Working Group WRB, 2006). The mineralogical composition of the clay fraction of the diagnostic horizon of 


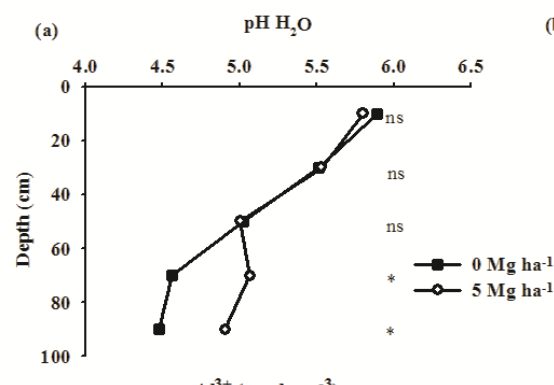

(b) $\quad \mathrm{pH} \mathrm{CaCl}_{2}$
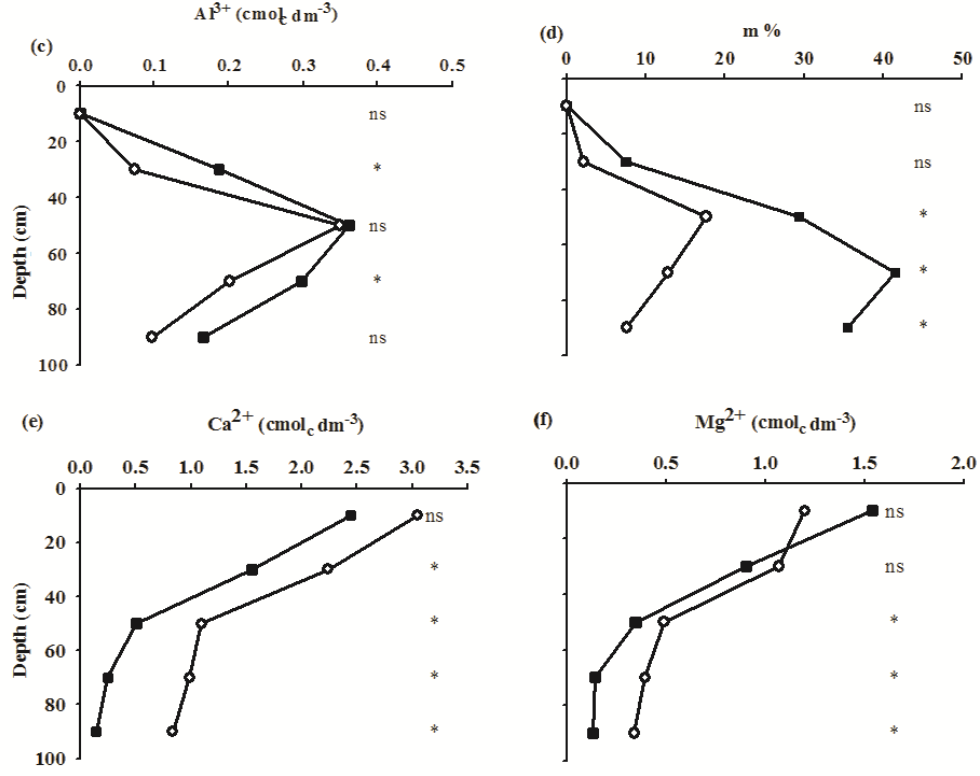

(f) $\mathrm{Mg}^{2+}\left(\mathrm{cmol}_{\mathrm{c}} \mathrm{dm}^{-3}\right)$
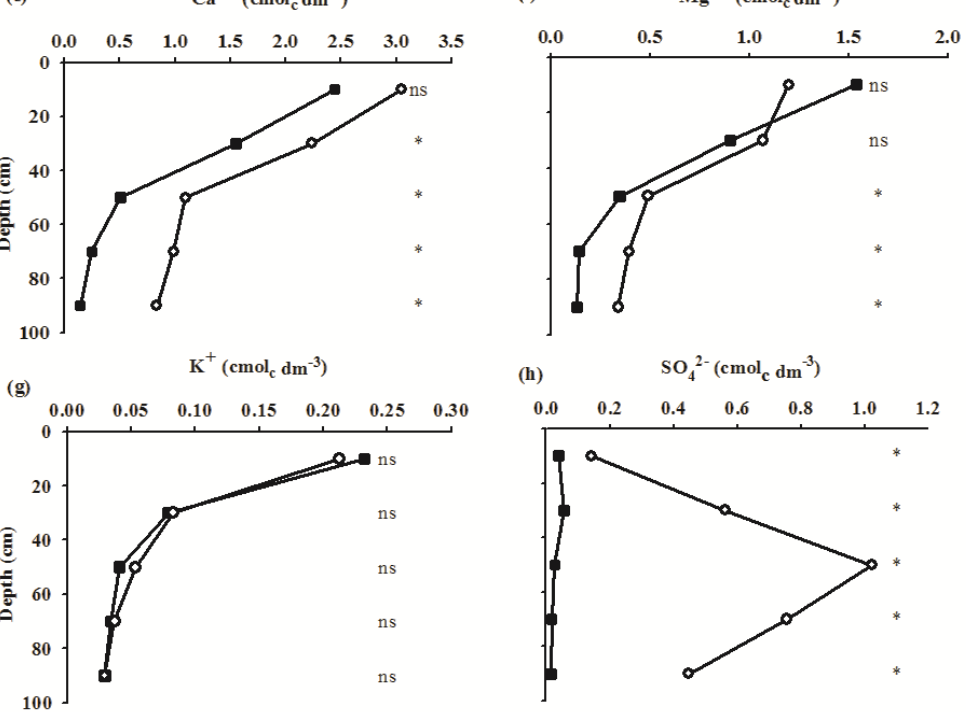

Fig 2. $\mathrm{pH}$ in $\mathrm{H}_{2} \mathrm{O}(\mathrm{a}), \mathrm{pH}$ in $\mathrm{CaCl}_{2}$ (b), aluminum content $\left(\mathrm{Al}^{3+}\right)$ (c), aluminum saturation ( $\mathrm{m} \%$ ) (d), exchangeable calcium $\left(\mathrm{Ca}^{2+}\right)(\mathrm{e})$, exchangeable magnesium $\left(\mathrm{Mg}^{2+}\right)$ (f), exchangeable potassium $\left(\mathrm{K}^{+}\right)(\mathrm{g})$ and sulfate content $\left(\mathrm{S}_{-} \mathrm{SO}_{4}{ }^{2-}\right)(\mathrm{h})$, in five layers $(0-20$; 20-40; 40- 60, 60-80, and 80-100 cm) of an Oxisol after the third ratoon crop in response to gypsum rates applied at sugarcane planting (50 months after application). * Significant by the $t$ test $(\mathrm{p} \leq 0.05)$.

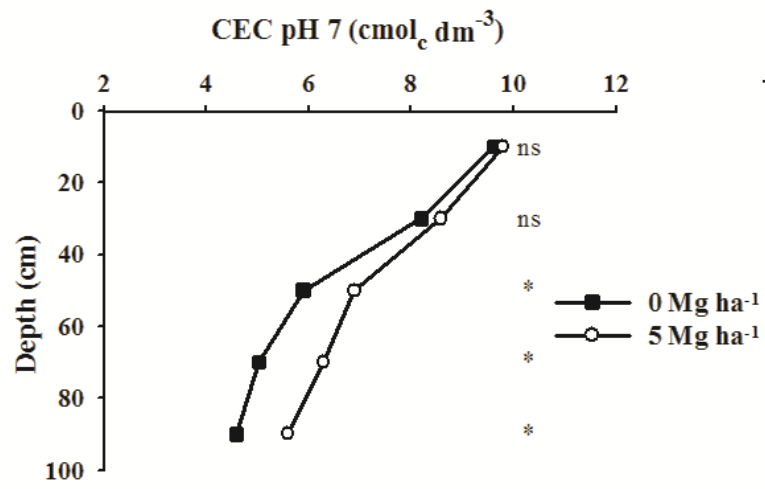

Fig 3. Cation exchange capacity (CEC pH 7) in five layers $(0-20 ; 20-40 ; 40-60 ; 60-80$, and 80-100 cm) of an Oxisol after sugarcane third ratoon crop in response to gypsum rates applied at sugarcane planting (50 months after application).* Significant by the t test $(\mathrm{p} \leq 0.05)$. 


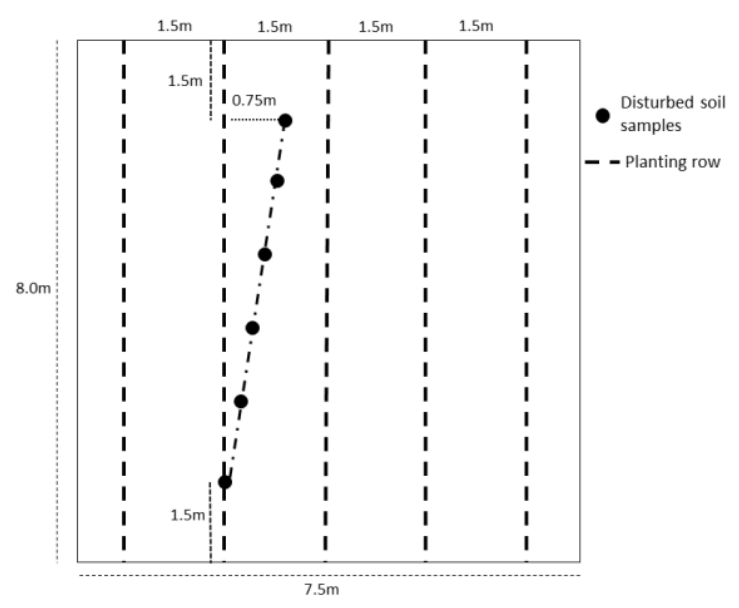

Fig 4. Sampling plan of disturbed soil showing the six points of collection located in and between the rows cultivated with sugarcane.

the studied soil consisted of: kaolinite $\left(634 \mathrm{~g} \mathrm{~kg}^{-1}\right)$; gibbsite $\left(195 \mathrm{~g} \mathrm{~kg}^{-1}\right)$; hematite $\left(108 \mathrm{~g} \mathrm{~kg}^{-1}\right)$; and goethite $\left(61 \mathrm{~g} \mathrm{~kg}^{-1}\right)$.

The experimental area had been deforested nearly 35 years before, and was maintained under spontaneous vegetation with predominance of grasses (Brachiaria decumbens and Andropogon gayanus) with no grazing animals. In October 2008, the area was divided into four plots and sampled at depths of $0-20,20-40$ and $40-60 \mathrm{~cm}$ for the determination of soil chemical properties (Table 1).

In February 2009, the lime and fertilizer rates were calculated as described by Sousa and Lobato (2004). Dolomitic lime $(\mathrm{CaO} 36 \%$ and $\mathrm{MgO} 17 \%)$ was manually applied at a rate of $7.08 \mathrm{tha}^{-1}$ to raise base saturation in the 0 $40 \mathrm{~cm}$ layer to $50 \%$. The lime was incorporated with a disc harrow to a depth of about $20 \mathrm{~cm}$, followed by plowing with a moldboard plow to a depth of about $40 \mathrm{~cm}$. Thereafter, 240 $\mathrm{kg} \mathrm{ha}^{-1} \mathrm{P}_{2} \mathrm{O}_{5}, 120 \mathrm{~kg} \mathrm{ha}^{-1} \mathrm{~K}_{2} \mathrm{O}$ and a source of micronutrients (100 kg ha ${ }^{-1}$ fritted trace elements (FTE BR 10)) were applied as corrective fertilization and incorporated into the soil with a harrow to a depth of $20 \mathrm{~cm}$.

In March 2009, Crotalaria juncea was sown in the experimental area $(20$ seeds per meter, rows spaced $45 \mathrm{~cm}$ apart), a common practice in the South Central region when sugarcane is replanted. The green manure was cut with a crop chopper in the flowering stage.

\section{Sugarcane characteristics}

The sugarcane (Saccharum spp.) variety RB867515 was planted in the dry season, in July 2009. Furrows were drawn (depth $\sim 40 \mathrm{~cm}$ ), in which fertilization was applied: urea (42 $\left.\mathrm{kg} \mathrm{ha}^{-1} \mathrm{~N}\right)$ and triple superphosphate $\left(183 \mathrm{~kg} \mathrm{ha}^{-1} \mathrm{P}_{2} \mathrm{O}_{5}\right)$. The nine-month-old plant cane seedlings had been propagated in the experimental area of Embrapa Cerrado. Then, three parallel stalk segments were planted to ensure the sprouting of at least 12 buds per meter.

Four sprinkle irrigations (4, 14 and 17 August and 17 September 2009) with $25 \mathrm{~mm}$ each were applied to promote bud sprouting after planting. During the experiment, weeds were controlled with herbicide spraying and hand weeding. In November 2009 , urea $\left(60 \mathrm{~kg} \mathrm{ha}^{-1} \mathrm{~N}\right)$ and potassium chloride $\left(150 \mathrm{~kg} \mathrm{ha}^{-1} \mathrm{~K}_{2} \mathrm{O}\right)$ were top-dressed.

The cane was harvested manually, without burning the trash, in August 2010. To induce intensive ratoon regrowth, supplementary irrigation was applied twice, at a level of 57.4 $\mathrm{mm}$ each, one and two weeks after harvest. Maintenance fertilization of the first ratoon crop and ammonium nitrate $\left(120 \mathrm{~kg} \mathrm{ha}^{-1} \mathrm{~N}\right)$ and potassium chloride $\left(150 \mathrm{~kg} \mathrm{ha}^{-1} \mathrm{~K}_{2} \mathrm{O}\right)$ was applied in November 2010, at the beginning of the rainy season. The harvest of the first ratoon occurred in August 2011, shortly after which the straw was chopped by a crushing machine Triton ${ }^{\circledR}$ straw residue chopper. In November 2011, sidedress fertilization of the second ratoon was held by applying $120 \mathrm{~kg} \mathrm{ha}^{-1} \mathrm{~N}, 50 \mathrm{~kg} \mathrm{ha}^{-1} \mathrm{P}_{2} \mathrm{O}_{5}$ and 150 $\mathrm{kg} \mathrm{K} \mathrm{K}_{2} \mathrm{O} \mathrm{ha}^{-1}$. The second ratoon was harvested in August 2012. Maintenance fertilization of the third ratoon consisted of the same amounts and N, P and K sources as for the second ratoon, and harvest took place in August, 2013. The crop practices were applied by the same methodology as for the first and second ratoon. The gypsum treatment $\left(\mathrm{CaSO}_{4} \cdot 2 \mathrm{H}_{2} \mathrm{O}\right)$ was applied in July 2009 by broadcasting over the soil surface after planting sugarcane. The gypsum dose was calculated by the expression $[\mathrm{Y}=75 \mathrm{X}]$, where $\mathrm{Y}$ is the gypsum rate (base of $15 \%$ sulfur), expressed in $\mathrm{kg} \mathrm{ha}^{-1}$, and $\mathrm{X}$ the clay content $(\%)$ in the $40-60 \mathrm{~cm}$ layer, as described by Sousa and Lobato (2004).

\section{Treatments and experimental design}

Two treatments were used: a control with $0 \mathrm{Mg} \mathrm{ha}^{-1}$ and a dose of $5 \mathrm{Mg} \mathrm{ha}^{-1}$ gypsum, as recommended for the studied soil. The experiment was arranged in a randomized block design with four replications. The experimental plots consisted of five $8-\mathrm{m}$ long rows of $\left(60 \mathrm{~m}^{2}\right)$, spaced $1.5 \mathrm{~m}$ apart.

\section{Soil sampling and determination of chemical attributes}

Soil samples were collected in September 2013, a month after harvesting the third ratoon crop. In the $0-5$ and $5-10 \mathrm{~cm}$ layers, sampling was done with a volumetric ring $\left(100 \mathrm{~cm}^{-3}\right.$ and diameter $5 \mathrm{~cm}$ ) and in the other layers $(10-20 ; 20-40 ; 40$ $60 ; 60-80$, and $80-100 \mathrm{~cm}$ ), with a Dutch auger. One composite sample per experimental plot was blended. These composite samples consisted of six equidistant sub-samples, one from the row and five from the interrow. Sub-samples were collected to represent the heterogeneous system in and between the rows (Fig 4).

For the chemical analyses, the soil samples were ground, air-dried and sieved ( $2 \mathrm{~mm}$ mesh). Then the $\mathrm{pH}$ of water and 
calcium chloride $\left(\mathrm{CaCl}_{2}\right)$ were determined, as well as exchangeable potassium $\left(\mathrm{K}^{+}\right)$by flame photometry; potential acidity $(\mathrm{H}+\mathrm{Al})$ and exchangeable aluminum $\left(\mathrm{Al}^{3+}\right)$ by titration; calcium $\left(\mathrm{Ca}^{2+}\right)$ and magnesium $\left(\mathrm{Mg}^{2+}\right)$ by atomic absorption spectrophotometry. Sulfur $\left(\mathrm{SO}_{4}^{2-}\right)$ was extracted with monobasic calcium phosphate and quantified by inductively coupled argon plasma for optical emission spectroscopy (ICP-OES). Based on these analyses, we calculated the cation exchange capacity (CEC) at soil $\mathrm{pH}=7$ and aluminum saturation (m). All chemical analyses were carried out as described by Embrapa (1997).

The plant and ratoon cane crops were harvested by hand without straw removal by burning (green cane). The harvested area consisted of $5 \mathrm{~m}$ of the three central rows per plot, disregarding $1.5 \mathrm{~m}$ at either end, totaling $22.5 \mathrm{~m}^{2}$. We evaluated the cane and sugar yield, according to the protocols of the council of sugarcane, sugar and alcohol producers of the State of São Paulo (CONSECANA).

\section{Statistical analysis}

The following model was used for analysis of variance of cane and sugar yield: $Y_{i j}=\mu+B_{i}+T_{j}+$ error (ij).

For analysis of variance of the chemical properties in the soil layers we used: $\mathrm{Y}_{\mathrm{ijm}}=\mu+\mathrm{B}_{\mathrm{i}}+\mathrm{T}_{\mathrm{j}}+$ error (ij) $+\mathrm{C}_{\mathrm{m}}+\mathrm{TC}_{\mathrm{jm}}+$ error (ijm), where $\mu=$ overall data mean; $\mathrm{B}=$ block ( $\mathrm{i}=$ $1,2,3,4) ; \mathrm{T}=$ treatment $(\mathrm{j}=1,2) ; \mathrm{C}=$ layer $(\mathrm{m}=1,2,3,4,5)$. The $0-20 \mathrm{~cm}$ layer was considered as the weighted mean of the layers 0-5, 5-10 and 10-20 cm; error = experimental error. Analysis of variance was performed using PROC MIXED of software SAS 9.1 (Statistical Analysis System), and in case of significance, the $\mathrm{t}$ test $(\mathrm{p}<0.05)$ was applied for mean comparison.

\section{Conclusion}

Gypsum application induced an increase in cane and sugar yield in four successive cycles. In the deeper soil layers, gypsum application increased the $\mathrm{pH}$ values in $\mathrm{H}_{2} \mathrm{O}(60-100$ $\mathrm{cm})$ and $\mathrm{pH}$ in $\mathrm{CaCl}_{2}(40-100 \mathrm{~cm})$ and reduced $\mathrm{Al}^{3+}$ saturation in sugarcane. Gypsum application resulted in higher $\mathrm{Ca}^{2+}, \mathrm{Mg}^{2+}$ and $\mathrm{SO}_{4}{ }^{2-}$ concentrations in the soil profile $(0-100 \mathrm{~cm})$ at higher proportions in the $20-100 \mathrm{~cm}$ layer for $\mathrm{Ca}^{2+}$ and $\mathrm{SO}_{4}{ }^{2-}$. In addition, gypsum promoted increase in cation exchange capacity in the subsurface layers (40-100 $\mathrm{cm})$. Therefore, gypsum application can improve the chemical conditions of the soil to increase sugarcane productivity in the Cerrado.

\section{Acknowledgements}

C.C Figueiredo thanks CNPq (Conselho Nacional de Desenvolvimento Científico e Tecnológico) for the Research Productivity Fellowship.

\section{References}

Adami M, Rudorff BFT, Freitas RM, Aguiar DA, Sugawara LM, Mello MP (2012) Remote sensing time series to evaluate direct land use change of recent expanded sugarcane crop in Brazil. Sustainability. 4:574-585.

Almeida HJ, Cruz FJR, Pancelli MA, Flores RA, Vasconcelos RL, Prado RM (2015) Decreased potassium fertilization in sugarcane ratoons grown under straw in different soils. Aust J Crop Sci. 9:596-604.
Basnayake J, Jackson PA, Inman-Bamber NG, Lakshmanan $P$ (2012) Sugarcane for water-limited environments. Genetic variation in cane yield and sugar content in response to water stress. J Exp Bot. 63:6023-6033.

Battie-Laclau P, Laclau JP (2009) Growth of the whole root system for a plant crop of sugarcane under rainfed and irrigated environments in Brazil. Field Crop Res. 114:351360.

Caires EF, Feldhaus IC, Barth G, Garbuio FJ (2002) Lime and gypsum application on the wheat crop. Sci Agric. 59:357-364.

Caires EF, Churka S, Garbuio FJ, Ferrari RA, Morgano MA (2006) Soybean yield and quality a function of lime and gypsum applications. Sci Agric. 63:370-379.

Caires EF, Joris HAW, Churka S (2010) Long-term effects of lime and phosphogypsum additions on no-till corn and soybean yield and soil chemical properties in southern Brazil. Soil Use Manage. 27:45-53.

Cakmak I (2013) Magnesium in crop production, food quality and human health. Plant Soil. 368:1-4.

EMBRAPA (1997) Manual de métodos de análise de solo. 2nd edn. Embrapa Sistema de Informação, Brasília.

EMBRAPA (2013) Sistema brasileiro de classificação de solos. Embrapa Sistema de Informação, Brasília.

CONAB - Companhia Nacional de Abastecimento (2015) Séries históricas. Available: http://www.conab.gov.br/ conteudos.php?a=1252\& (accessed 2015 jan).

FAO, IUSS Working Group WRB (2006) World Reference Base for Soil Resources, 2nd edn. World Soil Resources Reports No. 103. FAO: Rome.

Hernandes TAD, Bufon VB, Seabra JE (2014) Water footprint of biofuels in Brazil: assessing regional differences. Biofuel Bioprod Bior. 8:241-252.

Landell MGA, Prado H, Vasconcelos ACM, Perecin D, Rossetto R, Bidoia MAP, Silva MA, Xavier MA (2003) Oxisol subsurface chemical attributes related to sugarcane productivity. Sci Agric. 60:741-745.

Lima RC, Mello LM, Yano EH, Silva JO, Cesarin AL (2013) Modalities for soil preparation and gypsum application in Ultisol: stem productivity of sugarcane. Eng Agric. 33:1180-1190.

Macedo IC, Seabra JEA, Silva J (2008) Greenhouse gases emissions in the production and use of ethanol from sugarcane in Brazil: The 2005/2006 averages and a prediction for 2020. Biomass Bioenerg. 32:582-595.

Marschner H (2012) Mineral nutrition of higher plants, 3rd edn. Academic Press, London.

Nora DD, Amado TJC (2013) Improvement in chemical attributes of Oxisol subsoil and crop yields under no-till. Agron J. 105:1393-1403.

Pavan MA, Bingham FT, Pratt PF (1982) Toxicity of aluminum to coffee in Ultisols and Oxisols amended with $\mathrm{CaCO}_{3}$ and $\mathrm{CaSO}_{4}$. Soil Sci Soc Am J. 46:1201-1207.

Pauletti V, Pierri LD, Ranzan T, Barth G, Motta ACV (2014) Long-term effects of the application of gypsum and lime in a no-till system. Rev Bras Cienc Solo. 38:495-505.

Reeve NG, Sumner ME (1972) Amelioration of subsoil acidity in Natal Oxisols by leaching of surface applied amendments. Agrochemophysica. 4:1-6.

Ritchey KD, Sousa DMG, Lobato E, Correia O (1980) Calcium leaching to increase rooting depth in a Brazilian savannah Oxisol. Agron. J. 72:40-44.

Ritchey KD, Silva SE, Costa VF (1982) Calcium deficiency in clayey $\mathrm{B}$ horizons of savannah Oxisols. Soil Sci. 133:378-382. 
Ritchey KD, Feldhak CM, Clark RB, Sousa DMG (1995) Improved water and nutrient uptake from subsurface layers of gypsum-amended soils. In: Karlen DL, Wright RJ, Kemper WO (ed) Agricultural utilization of urban and industrial by-products. American Society of Agronomy: Madison.

Schofield RK, Taylor AW (1955) The measurement of soil pH. Soil Sci Soc Am J. 19:164-167.

Smith DM, Inman-Bamber NG, Thorburn PJ (2005) Growth and function of the sugarcane root system. Field Crop Res. 92:169-183.

Sousa DMG, Lobato E (2004) Cerrado: Correção do solo e adubação. Embrapa, Planaltina.

Soil Survey Staff (1998) Keys of Soil Taxonomy. United States Department of Agriculture: Washington.

Soratto RP, Crusciol CAC (2008) Dolomite and phosphogypsum surface application effects on annual crops nutrition and yield. Agron J. 100:261-270.
Crusciol CAC, Artigiani ACCA, Arf O, Carmeis Filho ACA, Soratto RP, Nascente AS, Alvarez RCF (2016) Surface application of lime-silicate-phosphogypsum mixtures for improving tropical soil properties and irrigated common bean yield. Soil Sci Soc Am J. 80:1-13.

Thangavelu S, Rao KC (2006) Sulphur uptake by sugarcane genetic stocks and its relationship with the uptake of other nutrients, and sugar productivity. Sugar Tech. 8:143-147.

Tuteja N, Mahajan S (2007) Calcium signaling network in plants: an overview. Plant Signal Behav. 2:79-85.

Waclawovsky AJ, Sato PM, Lembke CG, Moore PH, Souza GM (2010) Sugarcane for bioenergy production: an assessment of yield and regulation of sucrose content. Plant Biotechnol J. 8:263-276. 